\title{
DOSSIÊ
}

\section{A Colonialidade e a Emancipação no filme Emitai de Sembène Ousmane (Senegal, Anos 1970)}

\author{
The Coloniality and Emancipation in the movie Emitai of \\ Sembène Ousmane (Senegal, 1970's)
}

\author{
Vinicius Pinto Gomes \\ Mestre em História pela UDESC \\ orcid.org/0000-0003-2988-552X \\ vgomes19@gmail.com
}

\begin{abstract}
RESUMO: O presente artigo pretende analisar o filme Emitai (1971), dirigido por Sembène Ousmane a partir de um diálogo com os estudos pós-coloniais e decoloniais, partindo de uma perspectiva africana dos acontecimentos. Para tanto, utilizaremos da análise do filme, articulando a narrativa cinematográfica com entrevistas feitas pelo diretor, além da análise dos cartazes que foram produzidos para os festivais internacionais em que o filme foi exibido. A história do filme narra a resistência de uma vila Diola no sul do Senegal contra o colonialismo francês, dessa maneira, trazemos a categoria de emancipação para discutir a política proposta por Sembène e como ela se deu na sua narrativa fílmica. O diretor e roteirista Sembène Ousmane é considerado um dos principais cineastas do cinema africano, servindo como influência para várias gerações posteriores de artistas e políticos, dentro e fora do continente africano.
\end{abstract}

PALAVRAS-CHAVE: Emancipação. Colonialidade. Cinema Africano.

\begin{abstract}
This article intends to analyze the film Emitai (1971), directed by Sembène Ousmane from a dialog with post-colonial and decolonial studies, starting from an African perspective on events. Therefore, we will use the film analysis, articulating the cinematographic narrative with interviews of the director, besides the analysis of the posters produced for the international festivals where the film was screened. The story of the movie narrates the resistance of a Diola village in southern Senegal against French colonialism, so, we bring the category of emancipation to discuss the policies proposed by Sembène and how it is done in his film narrative. Director and screenwriter Sembène Ousmane is considered one of the main film-makers of African cinema, serving as influence to several later generations of artists and politicians, both inside and outside the African continent.
\end{abstract}

KEYWORDS: Emancipation. Coloniality. African Cinema.

Emitai é um dos primeiros filmes de Sembène Ousmane, seu segundo longametragem, lançado em 1971. No filme, vemos a luta de uma vila Diola contra os tirailleurs sénégalais, o exército colonial francês. Durante esse processo, vemos a resistência de homens, mulheres e crianças contra a violência colonial. A narrativa nos 
mostra como aquela vila se articulou para combater e resistir aos acontecimentos trazidos pela colonialidade, no contexto da Segunda Guerra Mundial. O filme narra de maneira especial os fatos de dentro do território senegalês, na região ao sul do país, em Casamanse, lugar onde o diretor nasceu e foi criado, e onde também vive a maior parte da população Diola. A história é baseada em acontecimentos de fatos históricos, articulada com as observações do diretor sobre o seu contexto, o que a faz um testemunho do sentido que o cineasta quer colocar para a narrativa histórica, sob um ponto de vista fílmico.

O presente artigo se concentrará na análise fílmica da narrativa de Emitai, focando-se na categoria de recusa e como ela vai sendo montada na produção do filme a aparece nos personagens, no conflito dos homens e também no das mulheres. Mantendo, assim, a divisão de cenas que a montagem vai costurando em paralelo, nos acontecimentos de um e de outro segmento dentro da vila. Nesse processo de abertura do filme, é interessante pensar o aspecto do feminino que o diretor coloca como força motriz de transformação, com uma prática revolucionária dentro do cotidiano e na recusa aos moldes coloniais e da violência. A partir disso, podemos pensar como a categoria de emancipação aparece na história do filme, na construção da luta das pessoas e na construção da história em si.

O título Emitai é dito por Sembène como "Deus do Trovão", na língua Diola, e a primeira versão do filme seria uma história sobre An Sitoe, ou Aline Sitoe, na versão francesa. Ela era uma senegalesa que liderou o movimento de boicote às provisões para o esforço de guerra francês, particularmente, o impedimento da entrega do arroz. Quanto à sua história, nos debruçaremos mais à frente, questionando, inclusive, esse conflito ideológico entre Sembène e os acontecimentos. No início dessa discussão é importante fazer referência ao título do filme, porque ele é uma das primeiras significações do filme, o primeiro contato entre a obra e o espectador. $O$ diretor é quem costura o filme, com o seu título vem toda uma memória de outros trabalhos, mas o filme em si caminha quase sozinho, como uma que criança vai conhecendo e sendo conhecida pelo mundo.

\section{Um nome, um início de discussão}

Emitai é um nome africano, o primeiro título de um filme em Diola, é outro desconhecido, nos limites dessa pesquisa, pode haver mais uns que foram feitos ou estão sendo. A tradução do nome, segundo Sembène, é "Deus do Trovão". Foi com essa denominação que ele respondeu às perguntas sobre o que significaria "Emitai". Também é assim que o filme é creditado em várias outras línguas, italiano, espanhol, francês, inglês. Não há lançamento oficial no Brasil, portanto, nunca tivemos esse subtítulo, somente Emitai. Contudo, como a pesquisa é um tanto quanto dinâmica e se aventura conforme os ventos de informações recolhidas, essa tradução deve ser questionada, com base em novas descobertas.

Wilmetta J. Toliver-Diallo, uma pesquisadora que escreveu sobre a memória e patrimonialização de An Sitoe, aponta em uma nota que existem melhores traduções do que seria Emitai. Toliver-Diallo aponta, na terceira nota do seu texto, que existe um 


\section{Historias}

Revista do Corpo Discente do Programa de Pós-Graduação em História da UnB

Em TEMPO de HistóRIAS | Brasília-DF | n. 37 | p. 9-27 | jul./dez. 2020.

ISSN 2316-1191

equívoco interpretativo feito por Louis Vincent Thomas, antropólogo que pesquisou os Diola, em 1959. Ele teria interpretado que An Sitoe na sua primeira cerimônia teria feito uma tempestade, ignorando a relação entre chuva (emitai) e o Supremo (emit). A aldeia de Kabrousse, onde vivia An Sitoe não entendia a chuva como uma ocorrência natural, mas sempre um presente dos deuses.

A partir dessas informações, devemos articular algumas percepções sobre o filme, Sembène e os Diola. O título "Emitai - Deus do Trovão" não é necessariamente um equívoco. Como obra ficcional, ela tem relação com a mensagem que o diretor quer passar, no caso de um filme, também as proposições e intenções da distribuição do filme. Relacionar Emitai, um deus poderoso, com trovão faz relação com uma mitologia conhecida pelos europeus, afinal, é importante notar que esse subtítulo é recorrente em línguas europeias. Desconheço que haja essa construção com relação à África, inclusive, porque isso não é uma questão trazida no cartaz feito em Cuba. Portanto, se buscarmos a tradução do Diola sobre o título de Emitai, ele seria mais condizente com a ideia de "Deus da Chuva", sem tanto o caráter de poder, no sentido dado por uma concepção mais moderna e indicando mais para a ideia de vida e criação, o que também são imagens produzidas por uma mente embebida de imagens da modernidade eurocêntricas. Uma tradução sempre perde parte do sentido original. De qualquer forma, "Emitai-Deus da Chuva".

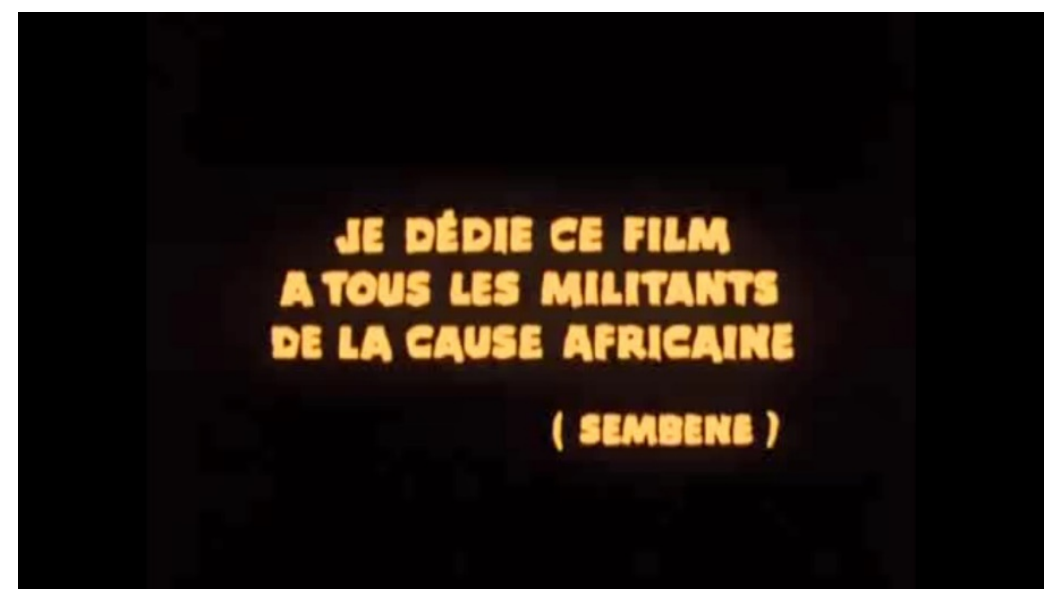

Imagem 1: Fotograma do filme Emitai (1971). Dirigido por Sembène Ousmane.

A imagem trazida acima é o primeiro fotograma apresentado em Emitai, um fundo preto, com uma inscrição em francês e traduzido como: "EU DEDICO ESTE FILME A TODOS OS MILITANTES DA CAUSA AFRICANA (SEMBENE)". As lutas de libertação ocorridas naquele contexto, especialmente, o passado ainda presente na guerra de independência travada por Guiné-Bissau contra os portugueses. Um território muito próximo de onde a história do filme se passa e cujo libertador, Amílcar Cabral $^{1}$, é muito influente no pensamento de Sembène. Em seguida, desenvolve-se

\footnotetext{
1 Amílcar Cabral foi um escritor, engenheiro agrônomo, político e intelectual marxista nascido em
} Guiné-Bissau e principal figura do PAIGC, o Partido Africano para a Independência da Guiné-Bissau e 


\section{Histortias}

Revista do Corpo Discente do Programa de Pós-Graduação em História da UnB

Em TEMPO de HistóriAs | Brasília-DF | n. 37 | p. 9-27 | jul./dez. 2020.

ISSN 2316-1191

todo o prólogo do filme, com o sequestro dos homens jovens da vila para lutarem na Segunda Guerra Mundial, o início do descontentamento dos mais velhos e a reunião entre os novos sequestrados recrutas e os oficiais brancos franceses. O final dessa introdução, bastante alongada, se dá com uma sequência de montagem com a imagem de um monumento aos soldados e de uma música de marcha militar francesa.

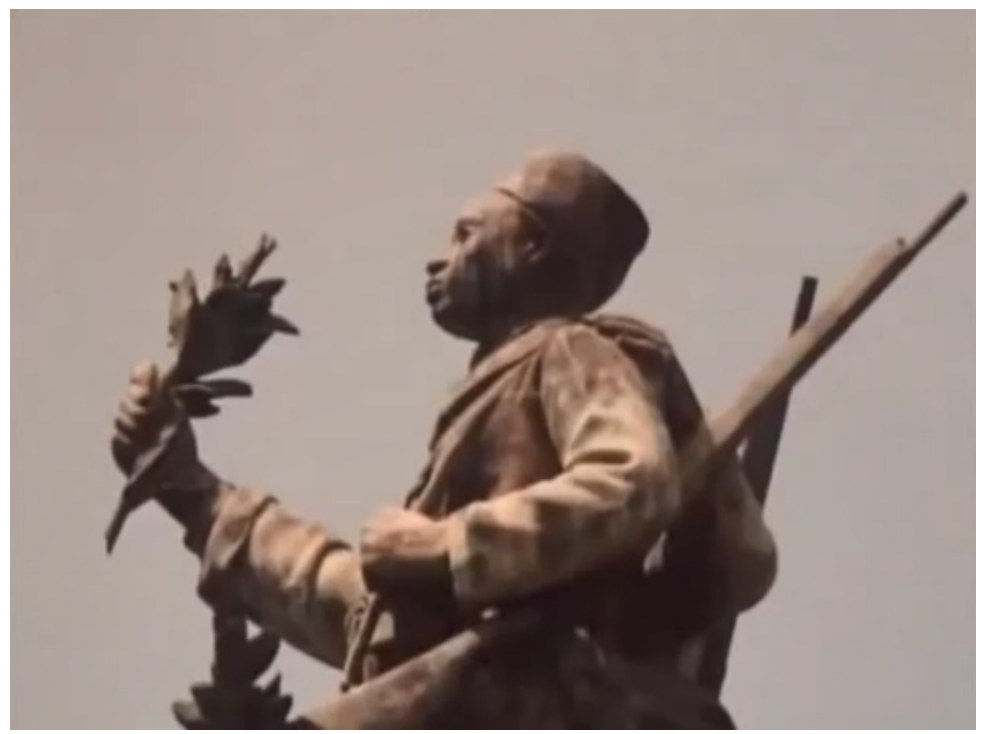

Imagem 2: Fotograma do Filme Emitai. Monumento aos criadores da África Ocidental Francesa e a sua Armada Negra. Emitai (1971), dirigido por Sembène Ousmane.

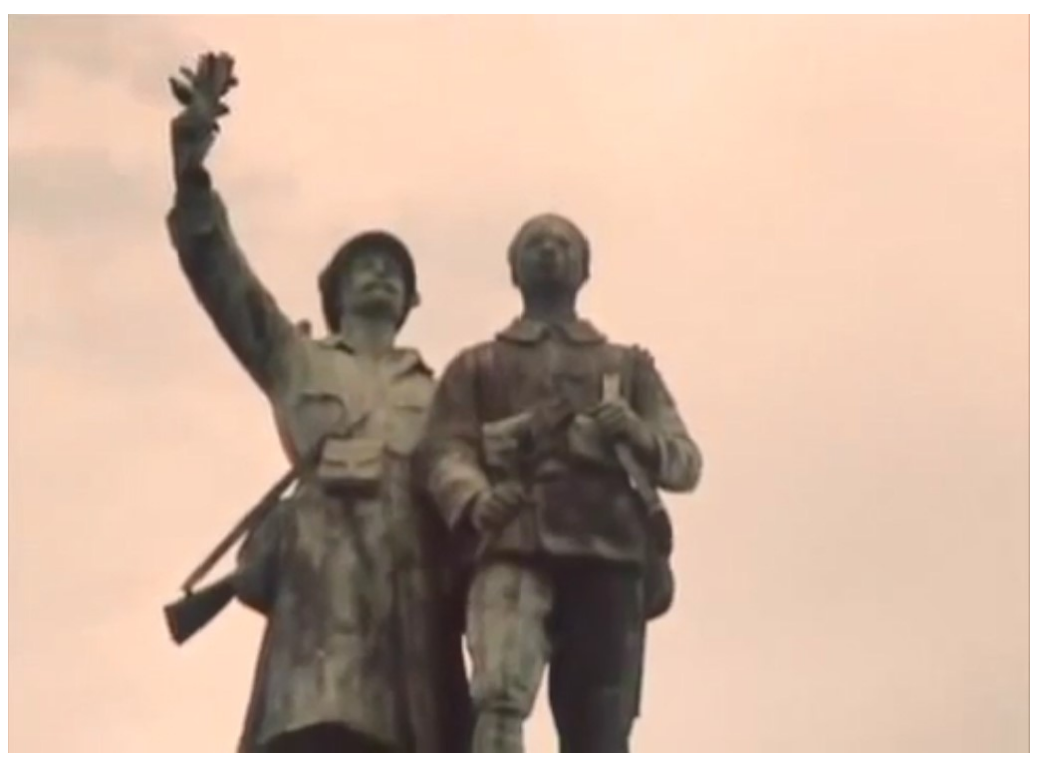

Imagem 3: fotograma do filme Emitai. Monumento Aos Criadores da África Ocidental Francesa e a glória da armada negra. Emitai (1971), dirigido por Sembène Ousmane.

Cabo Verde, sendo um dos seus fundadores. O seu trabalho político e intelectual caminha de maneira conjunta, pensando principalmente a libertação dos povos, especialmente no continente africano. Nesse sentido, ele pensa a cultura africana como uma arma para a emancipação dos povos e a revolução contra o capitalismo e o colonialismo. Do ponto de vista político a sua atuação a frente do PAIGC traz a libertação política de dois países, o que o faz uma figura central na construção nacional tanto de GuinéBissau, quanto de Cabo Verde. 
A montagem traz dois ângulos desse monumento. Na primeira cena, a câmera ao lado da estátua filma em perfil o soldado africano, enquadrando seu rosto, o rifle e a flor na sua mão que a segura na altura do peito. O movimento de câmera é de ir fechando no rosto desse soldado, detalhando mais a sua expressão em pedra. Na segunda cena da sequência, a imagem é de frente, mais aberta, como apresentada no excerto acima, revelando que o soldado africano não está sozinho, mas está sendo abraçado por um outro, um soldado francês, também armado e aparamentado, mas o seu movimento com a mão segurando a flor é para cima. A parte debaixo do monumento é revelado na terceira parte da montagem da cena, com o escrito ocupando toda a tela e a frase: "AVX CRETAVRS de L'Afrique Occidentale Francaise et A La Gloire de L'Armée Noire"2, sendo a escrita da letra 'u' seguindo a regra latina de se gravar a letra 'v'.

O monumento é uma homenagem da França aos soldados africanos que lutaram nas guerras, a "Armée Noire", a armada negra, mas não somente, porque a primeira inscrição coloca a homenagem aos criadores da A.O.F., ou seja, aos próprios franceses. Dessa forma, a estátua marca uma narrativa de homenagem do povo francês àprópria França e vice-versa, os africanos estão no segundo plano. O marco colocado ali é uma metáfora muito interessante da maneira como os franceses viam o seu papel no continente, as pessoas que lá habitavam e o seu colonialismo de maneira geral. A questão colocada, nessa montagem, mantendo um diálogo com Mbembe (2014), relaciona a metáfora em pedra com a dádiva da presença da cultura francesa, 0 "pesado fardo", cuja violência colonial moldou o território. A expressão do francês de apresentar o "outro" mostra esses valores de mentalidade colonial que via o seu mundo como superior e ali se revela o mundo "novo" da modernidade, um mundo melhor, ainda que os dois estejam armados. Isso se dá, na concepção de Mbembe, a partir da ideia colocada pelos franceses de que o modelo cívico republicano do seu país é o principal, o "cânon" do mundo, segundo a qual moldou e se monumentaliza, agradecendo a si mesmo.

A estátua faz uma espécie de saudação, um braço enrosca um abraço no africano e com o outro ele faz uma apresentação para o mundo, mas qual mundo? O sentido que Sembène coloca na cena, fixando na expressão da estátua', constrói uma relação de estranhamento do espectador para a tela, parece que o francês está apresentando as maravilhas da modernidade, ao mesmo tempo em que saúda a obra de guerra construída conjuntamente. A expressão da estátua do africano é bastante dura, não existe uma alegria, nem uma tristeza, a falta de emoção pode ser a apresentação dessa colonialidade da imagem, em que uma mentalidade eurocêntrica vê uma relação de parceria. Ou, por outro olhar, podemos ver a não expressão como um bobo que não entende os acontecimentos, está em suspensão da realidade, algo que é também uma sequela da colonialidade da imagem. Ao colocar o sequestro antes dessa sequência, o filme questiona essa formulação monumentalizada do africano que está junto do europeu no conflito, com uma irmandade nas armas, o que, nessa narrativa, é lida a contrapelo.

\footnotetext{
2 “Aos Criadores da África Ocidental Francesa e a Glória da Armada Negra.” (Tradução Livre).
} 
Revista do Corpo Discente do Programa de Pós-Graduação em História da UnB

Em TEMPO DE HIstóRIAS | Brasília-DF | n. 37 | p. 9-27 | jul./dez. 2020.

ISSN 2316-1191

O racismo é parte importante dessa forma eurocêntrica de ver e pensar o mundo, pois ele é constituinte da maneira como o mundo francês habitou no mundo. Como aponta Mbembe, a ideia de igualdade da Revolução Francesa montou uma humanidade que abstraia as diferenças na produção do seu humanismo. A raça é negada como fator de violência, pois, ao reconhecer o humano como um sujeito racional, em primazia, ela encontrava limites naqueles que eram considerados não racionais, portanto, não humanos. (MBEMBE, 2019, p.118). No final dessa discussão, o filosofo camaronês nota que o "ser humano" é sempre diferente e singular, na pluralidade. Dessa maneira, "nenhum pensamento sobre o sujeito será completo se esquecer que este só pode ser apreendido através de um distanciamento do si de si e só será tentado através de uma relação positiva com um ali" (Ibidem). Abrir caminhos e possibilidades outras é desestabilizar ordens e narrativas de modelos que negam, ou são incapazes de compreender as existências plurais numa humanidade amplificada.

Os filmes de Sembène podem ser vistos como um cinema que buscou girar as narrativas sobre o continente africano e as suas sociedades, positivando os corpos apresentados na tela e mostrando a pluralidade das expressões existentes. Assim, englobam várias formas de interpretar e dialogar com uma multiplicidade de experiências. Seus filmes trabalham com o aspecto mágico-cotidiano presente na cosmogonia, na oralidade e na ancestralidade dos povos da África Ocidental ${ }^{3}$. Atravessam a sua carreira também, em outro aspecto, uma visão mais materialista, como a corrupção das elites dirigentes, o conflito entre as operações da modernidade e a tradição, a sobrevivência cotidiana e o racismo. O seu biógrafo, Samba Gadijgo, na introdução do documentário dirigido pelo próprio sobre o Sembène, diz que quando ele viu na tela mulheres como sua mãe, tia, primas e irmãs, ele pode se perceber dentro das narrativas do cinema. A representatividade, portanto, é transformadora das experiências e produtora de mentalidades, atingindo a criação de projetos e ações que os grupos podem atingir nos processos coloniais. Uma sociedade que não se vê, pouco reflete sobre os seus acontecimentos. A quebra dos feitiços coloniais, da alucinação colonial, como diz Mbembe, é que faz do cinema uma forma de pedagogia decolonial, a partir de uma estética decolonial, como diz Achinte:

A estética descolonial deve assumir a tarefa de escutar em profundidade as culturas marginalizadas, daquelas às quais os danados fanonianos pertencem, de pensar em uma sociedade diferente, na qual a diversidade estética é uma possibilidade de entender outras concepções de beleza, do criativo, do próprio e do apropriado, do artístico e não é estranho para nós um tecido, um cobertor, um bastão, uma marimba de chonta, uma dança de bambuco, uma "juga" ou um

\footnotetext{
${ }^{3}$ A referência a ideia de África Ocidental nesse texto se dá pois esse conceito abarca uma série de culturas e mobilidades territoriais que os estados nacionais e as suas fronteiras não conseguem caracterizar. O que não significa que elas não sejam importantes, pois fazem parte da construção das identificações de africanos e africanas. Os Diola, o grupo que é citado nesse texto está no Senegal, mas também em Guiné-Bissau, ou seja, a sua presença não se articula somente com um estado nacional. Ao longo da sua carreira Sembène também trouxe a cultura Wolof para a tela e, assim como a cultura Diola, ela se encontra em mais lugares que não somente o Senegal. A discussão sobre identidades africanas é trazida por Kwame Appiah (1997). É importante não se confundir com o território colonial francês da A.O.F. (África Ocidental Francesa), cuja existência em nada tem a ver com a proposta que o texto faz referência, porque a ideia desse território era da dominação colonial contra a diversidade cultural e emancipação dos povos.
} 
Revista do Corpo Discente do Programa de Pós-Graduação em História da UnB

Em TEMPO DE HIstóRIAS | Brasília-DF | n. 37 | p. 9-27 | jul./dez. 2020.

ISSN 2316-1191

alabao, como expressão estética da espiritualidade afrodescendente, dado que "[...] o mistério da criação cultural continuará a escapar da razão" (ACHA, 1979, p.35), especialmente a razão ocidental que negligenciou outras racionalidades existentes em seus territórios conquistados e colonizados. (ACHINTE, 2017, p.38). ${ }^{4}$

A questão aberta por Achinte revela algumas possibilidades desse giro estético decolonial, escutando atentamente as narrativas de culturas outras. Inverter, ou, no caso, desorganizar as ordens estabelecidas é revelar outras concepções de presença, do belo, como diz o autor, e das formas de viver que são diversas. Dessa forma, uma estética decolonial cuja presença na diferença é basilar e aberta à criatividade cultural, os sentires e as formas outras de racionalidade, constrói uma humanidade muito mais próxima do "todo-mundo" glissantiano. Uma humanidade na diferença, o singular na pluralidade, precisa que as imagens sejam também mais plurais, apresentando as experiências de sujeitos e sujeitas outras. Além disso, para o diretor, era também preciso mostrar imagens que desafiassem os poderes vigentes, tanto o colonialismo, quanto o capitalismo, dois dos pés dos vários que conformam a "Matrix Colonial del Poder" (MIGNOLO, 2014).

Dessa forma, retornando para o problema da pesquisa, a questão que nos cerca, em primeiro plano, é a respeito da existência, no cinema de Sembène Ousmane, de um projeto de emancipação. O monumento nos foi a chave para discutir o colonialismo, mas, atrelado a ele, as várias formas de emancipação percebidas por autores africanos e latino-americanos em seus contextos, afirmando o giro estético decolonial proposto. Ainda que não seja um intelectual decolonial, pois essa afirmação seria cometer um anacronismo, o cineasta foi, sem dúvida, um militante contra a colonização. A sua luta foi contra as formas de poder que a França utilizava para continuar mantendo a sua influência dentro do Senegal, nessa mesma forma, foi contrário as elites africanas que negociavam o futuro do país nos órgãos internacionais muito mais em seu ganho do que no da sociedade.

Sendo assim, os ecos das histórias produzidas pelo diretor ressoam em várias das proposições críticas que os e as intelectuais do presente fazem com relação à presença da colonialidade. "O passado que não passa", concepção trazida por François Hartog (2015) e muito cara à história do tempo presente, é como podemos melhor categorizar a maneira como a colonialidade atua, o passado mal resolvido retorna, como um espírito amaldiçoado, como na cosmogonia africana, para incomodar os vivos. A presença da mentalidade colonial nas sociedades, reafirmada constantemente nas violências praticadas, faz com que também se mantenha vivo o passado produtor e reprodutor de violências.

\footnotetext{
4 Las estéticas decoloniales deben asumir la tarea de auscultar en la profundidad de las culturas marginalizadas, de esas culturas a las cuales pertenecen los Damnés fanonianos para pensarnos una sociedad diferente, en la cual la diversidad estética sea un posibilidad para entender otras concepciones de lo bello, de lo creativo, de lo proprio y de lo apropiado, de lo artístico y no nos resulte extraño un tejido, una manta, un bastón de mando, una marimba de chonta, un baile de bambuco, una "juga" o un alabao, como expresión estética de la espiritualidad afrodescendiente, habida cuenta que "[...] el misterio de a creación cultural se le seguirá escapando de la razón” (ACHA, 1979, p.35), sobre todo a la razón occidental que desatendió otras racionalidades existentes en sus territorios conquistados y colonizados. (ACHINTE, 2017, p.38).
} 
Assim, a emancipação também não pode ser uma figura única, mas diversa em suas formas, porque cada comunidade tem os seus próprios sentidos de "bem viver". Dessa forma, o projeto do cineasta versa sobre o Senegal, em primeiro lugar. Contudo, também é preciso ver o movimento plural do mundo, o encontro de saberes, em que a troca cultural é uma questão primordial. Portanto, ainda que local, existe um diálogo muito presente com vários outros projetos de emancipação sendo construídos nas Áfricas, nas Ásias e nas Américas, um encontro de povos subalternizados, dos danados da terra, como disse Fanon (1958). O caráter transnacional desse pensamento é um ponto importante para que possamos compreender esse projeto, porque ele não é único e nem tem uma só cabeça pensante, mas parte de grupos e do diálogo. Ao mesmo tempo em que não é completamente organizado, a sua organicidade é uma das suas principais virtudes e desafios, seja nos congressos pan-africanos, nas ruas das cidades dos países fora dos centro globais do capitalismo, nas organizações sociais da sociedade civil, nos partidos político ratificados com o combate ao capitalismo e na própria produção de cultura. A discussão fez parte do presente de produção de Emitai, em 1971, como também no de Camp de Thiaroye, em 1987. E, também, se faz no tempo presente deste texto, porque as existências de vários corpos estão em constante luta para sobreviver e continuar produzindo saberes e sentires no século XXI, como o fizeram no século XX. A partir disso, podemos considerar a ideia de Koselleck, dos vários presentes que habitam o nosso presente (KOSELLECK, 2014).

\section{Histórias Emancipatórias: um embate entre dois mundos}

Os filmes de Sembène Ousmane marcam um projeto de emancipação, girando as estéticas e colocando na tela corpos que antes não haviam estado no foco da câmera de uma maneira positiva. Esses corpos estão articulando-se contra um inimigo que nega as suas existências e os ameaça, os filmes mostram a movimentação das pessoas para a luta, as desobediências civis e o embate direto, quando imprescindível. Podemos elencar alguns momentos, como, por exemplo: as mulheres na aldeia escondendo o arroz, a articulação dos mais velhos na conversa com os deuses, as crianças que, entre idas e vindas, apoiam a aldeia, os soldados que, com o soldo menor, a comida, o tratamento se rebelam e marcam a história do Senegal, entre outros momentos. A emancipação é uma questão presente dentro dessas passagens.

A tela do cinema é invadida por narrativas de pessoas que questionam o sistema, desafiam as formas de poder e pretendem viver sem a presença do jugo colonial. Emancipar-se é desprender-se das maneiras com que a modernidade amassou a diversidade humana, para aqueles que nasceram dentro dela. $\mathrm{O}$ movimento de populações que estão à margem é de continuamente negar a mentalidade moderna, nas suas lógicas produtivistas e, por consequência, viver bem com o mundo ao redor. Em Emitai (1971), a aldeia não faz parte do sistema de trocas capitalista da modernidade, fica a margem e é explorada como mão-de-obra barata e material humano para a guerra.

O filme pretende também denunciar ao mundo os crimes cometidos pelo colonialismo no Senegal, a ação francesa dentro do território. Porém, é preciso reafirmar que a denúncia está sendo colocada sob o ponto de vista dos e das africanos e 
Revista do Corpo Discente do Programa de Pós-Graduação em História da UnB

Em TEMPO DE HIstóRIAS | Brasília-DF | n. 37 | p. 9-27 | jul./dez. 2020.

ISSN 2316-1191

africanas, porque é essa inversão de narrativas que Sembène está propondo, colocar a atenção nos corpos e nas falas dessas pessoas. Defender a vida, desobedecer aos invasores, tomar o campo, são táticas de ações diretas, articuladas a outras simbólicas que também fazem parte desse mosaico de recusas e resistências, com o objetivo de emancipar-se. Forma-se, nesse sentido, uma dupla vontade nessas narrativas que conversam entre si e são lançadas com o intuito de mostrar ao mundo e à própria população os acontecimentos, os fatos de uma história. $\mathrm{O}$ cinema de Sembène não tem a finalidade de ser uma historiografia, mas narra esses fatos históricos dentro de uma cinematografia, as regras e intenções, portanto, são distintas, ainda que exista um diálogo.

Para que possamos perceber essas questões, precisamos desmontar o filme, analisar algumas cenas de maneira mais pontual, outras nos auxiliam a completar o argumento. As entrevistas nos mostram as intenções de Sembène, sua forma de ver o mundo, a sua sociedade, o local e o global, seu pensamento na produção do filme e posterior a ele, pensando sobre a obra que construiu. Outras formas de arte que orbitam o filme, como os seus cartazes, também podem exprimir interpretações possíveis, pois foram feitas a partir do próprio filme, tem uma relação direta. Dessa forma, começamos a análise do ponto de vista do filme, logo na sequência seguinte ao que paramos, com o monumento aos combatentes.

O letreiro embaixo da cena revela que aquela ação acontece "um ano depois" dos acontecimentos que vimos anteriormente. A cena mostra as mulheres reunidas ao redor das sementes, elas enchem seus potes auxiliadas por um homem com uma pá que vai pegando do chão e vai completando. Com os vasilhames carregados e caminhando com eles em suas cabeças, saem de quadro. Chegam em fila única até o campo onde serão plantados. Elas derramam as sementes, distribuindo uniformemente nas valas e arrumando a vegetação. A ação não tem música, somente o som dos passos, dos pássaros, do encontro das mãos com as plantas e dos grãos caindo na terra. Esse som é muito diferente da sequência anterior, muito mais barulhenta, com uma música muito acentuada, o que ressalta a diminuição do ritmo, resultando em um quase silêncio, uma calmaria que contrapõe a ação anterior. Na cena seguinte vemos dois homens, cada um em um quadrado alagado revirando a terra, também com o barulho ritmado da atividade, sem música. O letreiro do filme passa nesse momento, com as letras amarelas no fundo claro, uma escolha que acaba dificultando um pouco o reconhecimento dos nomes.

Do ponto de vista de uma história de África, é importante notar como a produção de imagens foi importante na construção de mentalidades coloniais, dentro, mas especialmente fora do continente africano. As imagens colonizadas foram instrumentos para a justificativa das violências coloniais, descritas no capítulo anterior. O diretor busca fazer um regime de imagens outras. A construção dessas imagens na narrativa se dá por tentativa e erro, portanto, não é completamente afinada, nem muito menos está fixada em ideias muito bem consolidadas. Sendo essa uma questão da sua carreira, os filmes de Sembène são diferentes uns dos outros. ${ }^{5}$

${ }^{5}$ Em Emitai (1971), por exemplo, ele vai se utilizar da técnica de filtros e montagem para construir um mundo do "além", mostrando as entidades da cosmogonia Diola. Em Xala (1975), uma comédia que trata 
Revista do Corpo Discente do Programa de Pós-Graduação em História da UnB

Em TEMPO dE HISTóriAs | Brasília-DF | n. 37 | p. 9-27 | jul./dez. 2020.

ISSN 2316-1191

Algumas escolhas se repetem, outras não. Mas elas fazem parte desse processo de procurar uma forma de fazer cinema, uma questão que atravessa também a sua construção de narrativas fílmicas. Nesse sentido, um processo que também é emancipatório ao se posicionar em um embate de imagens, produzindo as suas próprias, concorrendo com a colonial, mas sem ser esse a totalidade do seu objetivo.

Um recurso que é trazido por Sembène e que tem uma recorrência em sua obra, quando faz sentido na narrativa, é a questão dos sons da natureza. Descrevemos, acima, como a cena em que as mulheres carregam e escondem o arroz e sem uma música, mas com o som dos passos, dos pássaros, do vento, dos grãos batendo na terra. Em uma cena anterior, duas mulheres procuram alguém através de um rio e se ouve o som do remo batendo na água e do deslizar do barco. As escolhas aqui são de uma ordem estética sobre uma forma africana de fazer cinema, uma "busca do cinema do silêncio", um "silêncio que fala". (SEMBÈNE; WEAVER, 2008, p. 30). O cinema de Sembène, ao colocar os sons da natureza, forma um contraponto a uma estética cinematográfica europeia ${ }^{6}$, em que os diretores colocam em todo momento a música, uma trilha que acompanha a cena e dá ritmo. Nesse sentido, a trilha sonora escolhida por Sembène é a natureza, por isso, quando a música entra no filme, ela sempre se encontra nas cenas dos brancos e muito pouco na dos africanos. A música sempre demarca uma situação que é estrangeira ao continente africano.

A sequência de abertura do filme, posterior ao prólogo, dá um sentido para o ritmo estético em Emitai. A música, por exemplo, é muito trazida nesses momentos por cinematografias ocidentais e ocidentalizadas, o diretor resolve essa questão de outra forma, buscando criar uma forma de ver o mundo africano, explorando os outros sentido, um ouvir misturado no ver. Mas que presta atenção na natureza, nos ritmos do trabalho e nos passos, esse último muito marcado nos filmes, traz uma certa tranquilidade na vila, um mundo que está em outro ritmo, dialogando com outras formas de existir, sem uma ansiedade moderna. O contraponto no ritmo dos soldados, com a música, já é uma outra forma de ver o mundo, tem mais pressa, movimenta-se com uma urgência que uma e outra, quando colocadas em comparação pela montagem, mostram dois mundos bem distintos. Os Diola caminham nos seus afazeres, certos do

sobre corrupção no governo do Senegal, o recurso de uma maldição faz parte do filme, mas a sua utilização não tem efeitos especiais e só vamos conhecer essa informação no final do filme, ainda que Xala signifique a forma de maldição que o filme trabalha. Em Moolaadé (2004) que trata mais especificamente sobre tradição e se utiliza de rituais com magia, os recursos especiais também não são utilizados, esse dispositivo narrativo adentra na história de maneira mais orgânica. Em Emitai e Moolaadé são trinta e três anos de diferença entre eles, uma diferença menor encontramos entre Xala e Emitai, mas a questão é afirmar que não há uma homogeneidade na utilização dos recursos fílmicos para problematizar o mundo mágico-cosmogônico, eles são dinâmicos, trocados conforme as necessidades da própria história.

${ }^{6}$ Um leitor poderia fazer um contraponto dizendo que ele se refere ao silêncio do cinema mudo. Esse é um tipo de filme que Sembène assistiu bastante quando jovem, mas é importante notar que ele não é um cinema do silêncio, porque é acompanhado de uma trilha sonora, muitas vezes, ao vivo, nos cinemas. Não havia som direto das cenas, nem o som das falas, somente gestos. O ritmo desses filmes era dado pela orquestra, deixando um legado sobre a forma como se entende a montagem dos filmes, em cenas tristes, uma trilha mais soturna, em outras de ação, a música acelera. E assim por diante. 
Revista do Corpo Discente do Programa de Pós-Graduação em História da UnB

Em TEMPO DE HISTóRIAs | Brasília-DF | n. 37 | p. 9-27 | jul./dez. 2020.

ISSN 2316-1191

que fazem, mas sem a pressa. Os Artilheiros Senegaleses caminham de maneira oposta, com passos projetados, quase correndo, saltando à frente.

O historiador David Marinho de Lima Júnior, na sua dissertação sobre Sembène, aponta que essa visão de contraponto, da rebeldia em ser encaixotado por uma forma de fazer cinema não deve ser lida como "fruto do colonialismo, mas sim um fruto de uma determinada região africana" (LIMA JUNIOR, 2014, p.17). A referência aqui é Casamanse, a região onde Sembène nasceu e onde os Diolas tem a sua principal morada, uma região cujas características são importante para compreender a visão de Sembène sobre os seus filmes, Lima Júnior afirma, em diálogo com Gadijgo, o biógrafo de Sembène, que "[os Diola] nunca estiveram sob uma monarquia e nunca tiveram a experiência de uma administração centralizada” (Ibidem). Ainda segundo ele:

[...] é notável desde o século XIX uma constante instabilidade política na região, primeiramente devido à violência contra os franceses e em seguida na formação de movimentos separatistas no pós-independência que estão em atividades até os dias de hoje na região. (Ibidem).

O peso do colonialismo não pode ser retirado, contudo, não pode ser definidor da maneira como Sembène construiu a sua arte. A recusa, palavra que usa nas suas entrevistas para pensar as suas histórias e personagens, está dentro de uma longa trajetória do povo de Casamanse, os Diola. Uma região que não tinha a mesma posição dentro das hierarquias coloniais francesas, como Dakar, por exemplo, na questão da cidadania daqueles que nascessem na capital. Essa era uma questão inexistente em Casamanse, o Indigenato era a ordem estabelecida e com ele várias formas de violência, transformadas em histórias no cinema de Sembène. Esse caldo cultural que o diretor viveu durante a sua constituição enquanto pessoa esteve presente quando ele se tornou um cineasta, trazendo a recusa para dentro da sua filmografia, uma versão africana das histórias.

Lima Júnior aponta que "a inquietude que levou a formação do artista e militante não é de origem europeia, sua estética, sua obra, são marcadas pela origem, e se converteram em instrumento para combater o colonialismo no campo da cultura." (Ibidem, p.18). Dessa forma, ao escolher mostrar, utilizando dos sons da natureza e do cotidiano, em tons naturais, as personagens africanas que aparecem em Emitai, está marcado pela sua origem, a região de Casamanse. O contraponto é marcado pela montagem das sequências, onde a música, em forma de marcha militar, mostra uma outra forma, mas ela também não é completamente ocidental. Mas uma versão africana, ou seja, uma interpretação africana de como eles veem essa modernidade/colonialidade que marcha pelo continente africano, que bate ansioso na terra.

\section{Histórias Emancipatórias: uma análise de Emitai}

Em Emitai, vemos essas duas visões entrando em conflito, o que é um contraponto sendo construído na introdução do filme, tencionado pelos acontecimentos do prólogo, vai se insuflando cada vez mais para ser um embate entre as duas formas, de fato. O cruzamento entre elas já aconteceu e coabitavam, com certas reservas e com 
uma distância, onde a França não via nada de positivo nos africanos e a resposta era próximo, não havia nada a ganhar com os franceses. A tensão acontece quando a guerra leva os jovens da vila. Além de nada ganharem, agora tinham perdidos seus filhos em um conflito que não era o deles, derradeiramente, chegam as ordens dos impostos em espécie, entregaram os filhos, agora devem entregar o arroz. $\mathrm{O}$ escalonamento da tensão é bem marcada, o cruzamento se torna um conflito.

A montagem introdutória nessa altura do filme é, em paralelo, a vila trabalhando, preparando a terra, semeando, cultivando e colhendo, tudo mostrado em uma sequência longa e com ângulos mais abertos, aproveitando a paisagem da região, mostrando o campo, o rio e as árvores. A sequência anterior com o sequestro, os soldados e a marcha cantada como trilha e imagem focada no monumento é comparativamente mais rápido do que a anterior. O que faz com que essa passagem pela vila diminua o ritmo do filme, o espectador tem a sua visão mais relaxada, com os sons diretos do movimento das pás entrando na terra e a revirando, dos passos na água e bem no fundo alguém canta uma música, esses elementos fazem o filme girar a sua forma de progresso. Ouvimos a música mais forte quando a câmera vai se aproximando das mulheres que cantam e permanecemos ouvindo quando a cena troca e vemos os homens carregando as pás, o tempo vai escurecendo, o que dá a entender que é o fim de um dia de trabalho. Os créditos cortam a música cantada e ouvimos o barulho dos pássaros revoando no rio, depois outros em cima de um coqueiro e terminamos com o barulho do vento e de uma mulher Diola que caminha no campo, ouvimos os seus passos.

A cena corta para a bandeira da França em um mastro, e a câmera desce mostrando um prédio baixo, um corte para uma parede com uma série de cartazes colados e novo corte para a ação no lado de fora, na rua, com calçamento e valetas para escorrer a chuva. O oficial branco, vestido com uniforme militar e um boné branco, vai em direção ao portão de entrada e é saudado por um artilheiro senegalês, com o seu característico chapéu cônico vermelho. O oficial bate continência sem parar a sua marcha e continua, com a câmera o seguindo de longe até a escadaria de entrada do prédio mostrado anteriormente. $\mathrm{O}$ oficial bate continência para o comandante na cena interna quando este chega na sua sala e começam o seu diálogo. O comandante lhe avisa que Dakar enviou uma ordem para que requisitassem o arroz em espécie, pois a colheita havia sido boa e eles precisavam alimentar as tropas na capital. A sua missão era pegar uma tropa completa de artilheiros e fazer duas coisas: trazer todo o arroz para Dakar e manter a ordem nas aldeias, porque o povo havia se rebelado contra o chefe da subdivisão. O comandante também aconselha ao tenente levar como suboficial o Sargento Badgi, um nativo da região e o melhor auxiliar.

De volta para a aldeia, três mulheres em um barco remam pelo rio, ouvimos o som dos remos tocando na água, não há diálogo. As três passam pela tela e a câmera as acompanha quando a terceira está prestes a sair de quadro. A câmera foca nela, uma senhora com o seu vestido de um vermelho claro e colarinho azul, olhando com atenção para frente enquanto segue remando. Do ponto de vista da praia, a câmera as enquadra chegando e, de maneira lenta, a cena vai progredindo. O corte nos revela um jovem em cima de um coqueiro, com uma corda amarrada entre ele e a árvore, na qual 
vai tencionando e subindo bem alto para colher as folhas de palmeira. As mulheres do barco são mostradas novamente, pegam os cestos, colocam em suas cabeças e caminham cantarolando em Diola, seguindo por um caminho até a vila. Essas novas cenas de trabalho no cotidiano são interrompidas com um novo corte, agora mais abrupto, onde nos é revelado o tocador de tambor que, com duas baquetas, bate em dois tambores. O jovem no coqueiro escuta e começa descer com atenção e pressa, mostrando que os tambores fizeram mudar o espírito das pessoas na cena. Alguma mensagem foi transmitida, mas o espectador a desconhece. Uma espécie de corneta é tocada por um homem em cima de uma árvore, seguindo seu próprio ritmo. As mulheres, então, surgem da noite com cestos de palha na cabeça, se encontrando com certa urgência, mas sempre caminhando, todas seguindo para o mesmo caminho. Passando em fila. Dois homens observam essa movimentação e um comenta ao outro: "as mulheres vão esconder o arroz", no que é respondido "não podemos entregar o arroz aos brancos", o primeiro então diz que "elas têm razão".

Uma imagem que auxilia para compreendermos essa discussão é a que mais aparece em pesquisas sobre Emitai, o seu cartaz, datado do ano de 1973, conforme a escritura no canto inferior direito. A primeira versão desse texto escrevia que o cartaz era de autoria desconhecida, porque a informação disponível se restringia apenas à imagem, estando ela como elemento de destaque no filme em blogs e site na internet. A continuação da pesquisa nos fez vasculhar mais uma vez a internet para tentar encontrar uma imagem de melhor qualidade que pudéssemos inserir. Mais do que uma imagem de qualidade, encontrei em uma imagem salva no site Pinterest outras informações. Ao inserir essa imagem, alguém escreveu em sua legenda "1973 Cuban poster for EMITAI (Ousmane Sembene, Senegal, 1971) Designer Dimas Poster Source [origem] Danish Film Institute". O modelo dissertativo não ajuda na transmissão dos sentimentos do investigador, entretanto, podemos dizer que a pesquisa surpreendeu. Diretamente, o próximo passo foi entrar no site do Danish Film Institute, no qual a legenda indicava ser a origem de onde estava guardado o cartaz. Porém, a parte do site que continha os arquivos não estava mais no ar inteiramente, continha poucas informações e nenhuma delas sobre Emitai diretamente. Dessa maneira, era preciso encontrar um outro caminho para a pesquisa, afinal, quem era Dimas?

A pesquisa, então, encontrou uma grande produção de cartazes feitos pelo Instituto Cubano del Arte e Industria cinematográficos (ICAIC), voltados para os filmes estrangeiros que eram recebidos no país. As iniciativas faziam parte do plano de cooperação internacional entre Cuba e vários países africanos, no contexto da luta contra o colonialismo, vista como uma luta contra o imperialismo capitalista. Não somente Emitai recebeu um cartaz, mas havia outros tantos filmes que os cartazes foram feitos diretamente pelos designers do ICAIC. A descoberta se deu ao nos depararmos com uma notícia sobre uma exposição desses cartazes no Museu de Artes Decorativas (MAD - Museé des Arts Décoratifs), realizada entre 31 de outubro de 2019 e 2 de fevereiro de 2020. Uma das imagens apresentadas como peças da exposição era um cartaz com relação ao primeiro de maio, creditado a Dimas, em parênteses o nome completo: Jorge Dimas Gonzales Linares. 
Revista do Corpo Discente do Programa de Pós-Graduação em História da UnB

Em TEMPO DE HIstóRIAS | Brasília-DF | n. 37 | p. 9-27 | jul./dez. 2020.

ISSN 2316-1191

O cartaz não foi, a princípio, encomendado por Sembène. Tinha uma motivação própria de diálogo com o público pelo órgão distribuidor. Por outro lado, existe uma possibilidade de que o diretor tenha visto e aprovado o trabalho, em muito pela captação, por parte do artista, de um dos espíritos do filme. O cartaz traduz em imagens uma questão que atravessa o filme, o incômodo com o colonialismo, nas cenas introdutórias, isso é bem capitalizado pela montagem. O espectador vai percebendo no filme essa transformação das relações sociais entre os Diola e os franceses, com os desmandos europeus frente a um povo que ainda tropeça nas respostas a esses acontecimentos. O artista Jorge Dimas Gonzales Linares consegue exprimir essas cenas que vão colocando em contraponto um mundo do outro. Dessa forma, os cartazes e as cenas são trazidos conjuntamente para discutir esse incômodo tornado conflito que o filme apresenta, ligado à história do povo do Senegal, a qual Sembène se preocupa em mostrar.

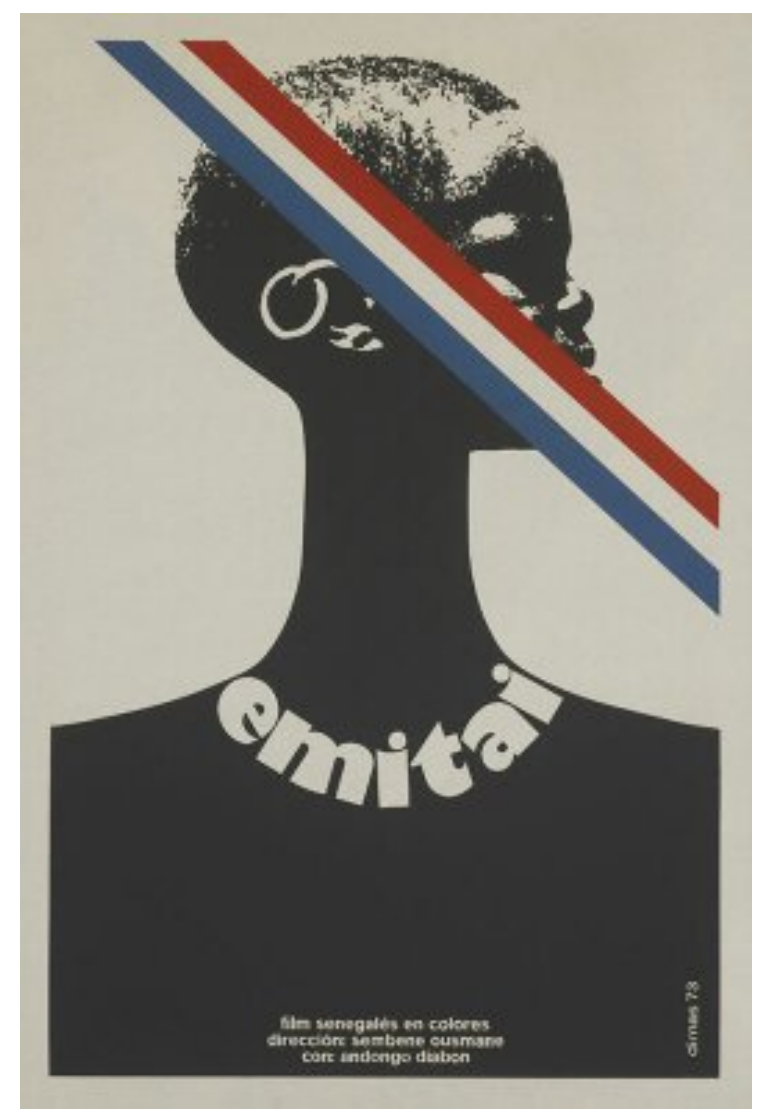

Imagem 4: Cartaz do Filme Emitai (1971) em Cuba. Diretor: Sembène Ousmane. Autoria: Jorge Dimas Gonzalo Linares.

O cartaz de um filme é uma apresentação dele, precisa instigar o público, chamar a sua atenção, fazer um trabalho imagético da sinopse, ao mesmo tempo em que não pode dar tantas informações assim. Os cartazes podem ser feitos pelos cineastas, mas, na maioria das vezes, são encomendas. Os cartazes da segunda metade do século XX possuíam mais relevância do que atualmente, moldando-se ao espírito do fazer cinematográfico da sua época. O cartaz de Emitai precisa inspirar-se no espírito do filme para poder revelar, em partes, o que o filme mostra em sua tela. Espiar por 
Revista do Corpo Discente do Programa de Pós-Graduação em História da UnB

Em TEMPO DE HISTóRIAs | Brasília-DF | n. 37 | p. 9-27 | jul./dez. 2020.

ISSN 2316-1191

uma fechadura, por uma janela fosca, ver algo com dificuldade, para comprar o ingresso.

O historiador da arte Didi-Huberman (2017) nos convida a desmontar a imagem, buscar seus elementos, para produzir uma leitura, junto com o seu contexto. A figura humana retratada no cartaz é uma pessoa africana, sem podermos concluir se um homem ou uma mulher, a figura é sem gênero. $O$ fundo claro, mas não branco, destaca a pele preta da figura, seu rosto é iluminado, revelando profundidade e detalhes na boca, nariz, olhos e cabelo. A sua orelha tem uma argola que atravessa a parte superior. Vemos a pessoa de perfil, com seus olhos mirando do seu ponto de vista a esquerda do quadro. Seu pescoço, muito mais alongado do que o comum termina na base com um colar de letras que formam a palavra "Emitai", no seu centro de seu peito as informações em espanhol que foram descritas acima.

A primeira camada com essa figura é atravessada por outra, mais a próximo de quem vê a imagem. Vemos uma bandeira da França que corta da esquerda para a direita da figura em diagonal, começando do início da nuca e terminando logo abaixo do lábio inferior. A bandeira que não tem um final, porque dá a sensação de estar correndo para fora do quadro e entra na figura de maneira bastante violenta. Ela corta a pessoa. Ao mesmo tempo em que divide a imagem em duas, no rosto acima do corte o detalhe é muito mais presente, vemos as sombras e algumas expressões. Abaixo da bandeira, os detalhes vão rareando até que se tornam muito mais simplificados, não há mais sombras e luz abaixo da bandeira, temos uma colorização mais crua. A escolha da posição de onde a bandeira atravessa a imagem também pode significar algumas proposições da visão do artista sobre o filme. Por exemplo, existe uma separação do sentido da audição dos outros, a boca está quase tapada.

Nesse sentido, as interpretações podem ir ao encontro de uma leitura onde a crítica produzida pelo diretor está no posicionamento de produzir uma narrativa que não silencie os e as africanos e africanas. Ao mesmo tempo, denuncia um atravessamento nos sentidos das sociedades africanas, e no ser africano que se encontra na história do filme sendo atingido pelo colonialismo. A bandeira francesa que atravessa a imagem está em um cruzamento com esse corpo africano que está na imagem, existe um incomodo que a imagem revela. Todos esses elementos podem auxiliar no entendimento do espírito do filme, do conflito que vai sendo construído, apontando, dentro da narrativa criada por Sembène, as justificativas para a revolta. $\mathrm{O}$ colonialismo francês, na imagem, é colocado como um incomodo violento, que transpassa esse corpo e o simplifica, desumaniza, ao mesmo tempo em que o pescoço alongado lembra o baobá, uma árvore sagrada que simboliza esse encontro do ser com a ancestralidade. O cartaz traz vários elementos que podemos pensar e que foram elencados a partir de uma interpretação, buscando descortinar a imagem a partir dela mesma e do filme, ainda que faltem elementos do diálogo com o artista desconhecido que produziu, em que poderíamos corroborar ou negar as interpretações.

O colonialismo denunciado no cartaz tem no filme a sua resposta. A França que vai construindo a tensão, provocando um sentimento de revolta na população Diola, marcha em direção à vila, em fila, abaixados na estrada cercada pela vegetação amarelada. Sua marcha é acompanhada pelo ritmo dos tambores. Os elementos antes 
separados entre uma cena e outra, o tambor e os soldados, vão sendo mesclados, marcando esse momento de preparação do conflito. O sargento Badgi ouve e reconhece os tambores e segue a sua marcha com os outros soldados. Embaixo da árvore, os líderes homens se encontram em um círculo, discutem o que devem fazer, entre eles o chefe da vila, Djimeko. A maioria acredita que é preciso consultar os deuses, porque temem mais a eles do que aos brancos ou a morte. O líder diz que respeita as divindades, o arroz foi abençoado por Salignam, mas que entregar o grão seria uma afronta à dignidade deles, não havia tempo para consulta, havia dito ele anteriormente. Por fim, com a lança na mão anuncia um desafio, diz que todo homem tem que morrer com uma lança na mão e quem se sentir homem deve segui-lo. Ninguém o segue.

Djimeko é saudado pelos homens, mais jovens, que o aguardam do lado de fora, alguns com lanças, outros com arcos e flechas. As pinturas em seus rostos mostram a sua preparação para a guerra. O líder, então, para em frente à sua tropa agachada e, sem proferir nenhuma palavra, os olha fixamente. $\mathrm{O}$ som que o espectador ouve é da música cantada para a sua saudação, uma música para a guerra. Djimeko atravessa pelo meio das pessoas e é seguido pelo olhar dos seus guerreiros, faz um chamado com sua lança empunhada, ao que é respondido. Todos correm pelo caminho gritando. $\mathrm{O}$ caminho escolhido pelo líder e por seus guerreiros é o da guerra e todos correm rumo a esse conflito. Os outros líderes acompanham com o olhar a movimentação, a poeira dos passos correndo atravessa o cercado de vegetação que marca o limite do lugar da reunião. Todos estão sentados, sem reação.

Um plano aberto da cena mostra um grupo de pessoas em linha caminhando pela vegetação, não há sons, somente os corpos que aceleradamente avançam pelo caminho. $\mathrm{O}$ silêncio é cortado por um instrumento de sopro, um homem levanta a sua cabeça de uma árvore para observar, um outro, mais jovem, é mostrado escondido no meio de outra árvore, observando. Os artilheiros aparecem correndo e o tenente grita “Adiante!". Todos correm para a linha de vegetação. Os Diola aparecem liderados por Djimeko, abaixados com as suas lanças por entre a vegetação que os artilheiros estão correndo. A batalha acontece na fronteira entre o campo mais aberto onde estão os artilheiros e a vegetação de onde os Diola arremessam as suas lanças e disparam os seus arcos. Os soldados se abaixam e contra atacam atirando, um dos primeiros a cair ferido é o próprio líder Djimeko. O conflito é bastante rápido, os fuzis disparam muito mais rapidamente do que os Diola conseguem arremessar as suas armas, alguns caem mortos, outros fogem correndo pela mata. Os artilheiros avançam pela vegetação em perseguição aos Diola e nós, espectadores, ouvimos somente os tiros, com o posterior silêncio no som, enquanto, na imagem, o menino em cima da árvore observa. No novo corte da cena, vemos os corpos dos Diola caídos no chão, todos mortos no conflito. 


\section{Historias}

Revista do Corpo Discente do Programa de Pós-Graduação em História da UnB Em TEMPO de HistóRIAS | Brasília-DF | n. 37 | p. 9-27 | jul./dez. 2020.

ISSN 2316-1191

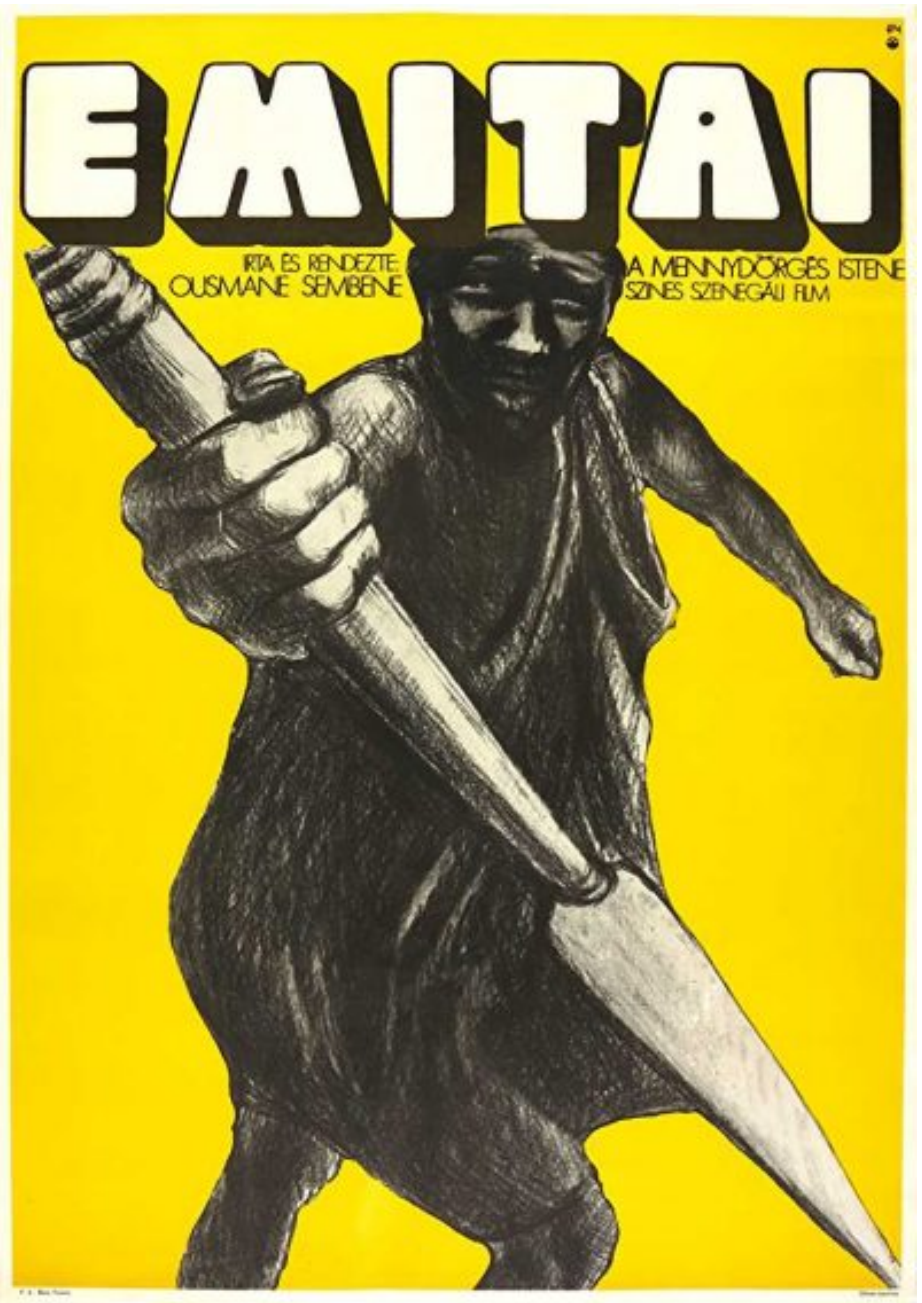

Imagem 5: Cartaz do filme Emitai (1971) na Hungria, datado de 1972. Diretor: Ousmane Sembène Autor: Desconhecido.

O cartaz acima também está registrado no site IMDB. Na sua legenda, encontra-se uma referência à Casa de Leilão Pest-Budai, em Budapeste, na Hungria. Nas suas redes sociais, eles dizem ser o lugar para se encontrar cartazes vintage, tais como os de Emitai. O exemplar original já foi vendido. Na descrição do cartaz mostra a data de 1972, mas a autoria permanece desconhecida. Também não é possível saber quem é que tem ele na parede. O cartaz tem uma proposta menos lírica do que a versão cubana, mas traduz uma parte do espírito do filme, mostrando o conflito, a resistência. $\mathrm{O}$ fundo em amarelo destaca a figura, reconhecidamente, um homem. Ele tem a sua cabeça virada para quem olha, mas seu olhar foge, fixa no acontecimento, as suas pernas, diferentemente, estão voltadas para a direita do quadro. Temos uma sensação de movimento, o homem está grafado como se estivesse se virando para a ação. Seu braço leva a lança para o primeiríssimo plano da imagem, dando todo o destaque ao objeto. O desenho tem uma elipse, pois não sabemos se ele vai atirá-la para frente, com o impulso que vem de trás. Ou se será jogado no chão. As duas ações são apresentadas no filme, em minutos bastante próximos um dos outros, mas não é possível discernir completamente. Contudo, quem discute e joga no chão a lança é 
Djimeko e este não parece ser ele, porque faltam mais detalhes em sua roupa que mostrem o status do personagem. A roupa do chefe tinha mais detalhes coloridos e ele usava o seu chapéu cônico.

A lança transforma completamente a questão final da mensagem passada pelos dois cartazes. Na versão húngara, a guerra é muito mais demarcada, vemos menos a França. O cartaz em questão relaciona-se mais com a resistência armada, com a luta direta. Sembène não coloca peso em uma ou em outra forma. Nas suas entrevistas, ele aponta que as mulheres lutam tanto quanto os homens. Uma questão cara, nesse sentido, é perceber que, em 1971, o diretor falava de como o propósito do seu filme era que "pertence as pessoas [the people] a decisão sobre seus próprios destinos, não os deuses" (HENEBELLE; SEMBENE. 2008, p.22). O cartaz segue essa linha, a arma pega com firmeza, no primeiro plano, voltada para quem visualiza, traz essa mensagem da luta no sentido dado pelo comunismo. "Eu vejo o cinema como uma arma política" (Ibidem), disse Sembène na mesma entrevista e completou com uma ideia que vai acompanhá-lo ao longo da sua carreira. Ele diz que "Eu sei bem que eu não vou poder mudar a realidade social senegalesa com um filme. Mas eu acho que um grupo de cineastas pode ajudar a acordar" (Ibidem). Falando em cinema, ele fala sobre como vê a transformação, sempre em grupo. Em outras entrevistas, ele chama a atenção do artista indo ao encontro das pessoas, do povo, o indivíduo não é revolucionário sozinho, precisa de um grupo.

O indivíduo ali na imagem olha para o além, mas mostra a lança para o público. Sua face está voltada também para o mesmo lugar. A composição faz esse convite, para que lutem com ele contra os seus inimigos, o colonialismo e o capitalismo. $\mathrm{O}$ mesmo Sembène diz que "não quero fazer filmes intelectuais, mas rodar filmes populares que falem as massas. Eu gosto do filme que fala com as massas, como Cinema Novo brasileiro. O cinema deve também ser um entretenimento" (Ibidem). A sua forma de fazer cinema ainda não estava completamente madura. Esse era o seu terceiro longametragem, no início dos anos de 1970. O cinema como arte ou como política já estava em franca produção, entretanto muitos diretores e diretoras produziam o cinema, testavam equipamentos e as formas de fazer e contar histórias. A produção desse cinema, em Sembène, se iniciava com um compromisso, se encontrar com o povo.

\section{Referências}

ACHINTE, Adolfo Albán. Prácticas creativas de re-existencia: más allá del alter... el mundo de lo sensible. Ciudad Autónoma de Buenos Aires: Ediciones Del Signo, 2017.

APPIAH, Kwame. Na Casa de Meu Pai: a África na filosofia da cultura. Rio de Janeiro: Contraponto, 1997.

BUSCH, Annett; ANNAS, Max. (Org). Ousmane Sembène: interviews. Jackson: University Press of Mississippi, 2008.

DIDI-HUBERMAN, Georges. Quando as Imagens Tomam Posição. Belo Horizonte: Editora da UFMG. 2017. 


\section{Hitistorias}

Revista do Corpo Discente do Programa de Pós-Graduação em História da UnB

Em TEMPO de HistóRIAS | Brasília-DF | n. 37 | p. 9-27 | jul./dez. 2020.

ISSN 2316-1191

HARTOG, François. Regime de Historicidade: presentismo e experiências do tempo. Belo Horizonte: Autêntica Editora, 2015.

KOSELLECK, Reinhart. Estratos do Tempo: estudos sobre história. Rio de Janeiro: Contraponto; Ed. PUC-Rio, 2014.

LIMA JUNIOR, David Marinho de. Descolonizando as mentes: Ousmane Sembène e a proposta de um cinema africano na década de 1960. 2014. Dissertação (Mestrado em História) - Departamento de História, Potifícia Universidade Católica do Rio de Janeiro, Rio de Janeiro.

MIGNOLO, Walter. Desobediencia epistémica: retórica de la modernidade, lógica de la colonialidade y gramática de la descolonialidad. CABA: Ediciones Del Signo, 2014.

MBEMBE, Achille. Crítica da Razão Negra. Lisboa: Antígona Editores, 2014.

MBEMBE, Achille. Sair da Grande Noite: ensaio sobre a África descolonizada. Petrópolis, RJ: Editora Vozes, 2019.

TOLLIVER-DIALLO, Willmetta J. "The Woman Who Was More Than a Man”: making Aline Sitoe Diatta into a National Heroine in Senegal. Canadian Journal of African Studies, 39:2, pp.340-362, 2013. 